\title{
RATE REGULATION IN OCEAN TRANSPORT: DEVELOPING COUNTRIES CONFRONT THE LINER CONFERENCE SYSTEM
}

The revolutionary growth of world trade in the 19th century facilitated the rapid economic development of those states we now term developed countries. ${ }^{1}$ Today the developing countries of the world beheve increased foreign trade is essential to their domestic economic growth. ${ }^{2}$ However, it is primarily the developed countries that continue to benefit from the expansion of world trade, ${ }^{3}$ and in overcoming this traditional advantage, the developing countries face special problems.

One such problem involves the present system of ocean transport of dry cargo. ${ }^{4}$ Most developing-country trade takes place with noncontiguous developed countries ${ }^{5}$ and is carried by sea. In 1968, developingcountry exports, consisting principally of primary products, ${ }^{6}$ accounted

1. See B. SöDERSTen, INTERnational Economics 113-18 (1970).

2. See generally Towards a New Trade Policy for Development, in 2 Proceedings of the United Nations Conference on Trade and DeVelopment 5-64, U.N. Doc. E/CONF. 46/141 (1964) [hereinafter cited as PRocEednas].

3. In 1968 , total developed-country exports were valued at 168 billion dollars, compared with developing-country exports of 43.6 billion dollars. While both figures represent an increase over previous years, the developing-country share of the world total is declining. 1 Statistical OfFice of the United Nations, 1968 World Trade ANNUAL xi (1969) [hereinafter cited as WorLd TRADE ANNUAL]. Some reasons for the inability of developing countries to capitalize on the growth of world trade are offered in Myint, The "Classical Theory" of International Trade and the Underdeveloped Countries, 68 EcoN. J. 317 (1958).

4. World transport of dry cargo (as opposed to tanker, or wet cargo, transport) is divided between two main sources of transport supply: liners and tramps. Liners provide services analogous to most common carriers, with fixed routes and regular sailing schedules. Tramps have no long-term restrictions on routes or sailings; rather, they operate on charter agreements within a competitive market. The types of commodities carried may differ between the two services, but there is competition in the transport of bulk commodities such as grains and raw materials. D. MARX, INTERNAtronal ShIPpIng Cartels 3, 223-29 (1953) [hereinafter cited as MarX]. Liners carried approxinately 25 percent of total seaborne trade in 1964 . Shipping and the World Economy 5, U.N. Doc. TD/B/C. 4/17 (1966).

5. In 1968, developing countries exported $32,427.4$ million dollars worth of trade to developed countries, compared to 6,752.8 million dollars worth of trade among themselves. Imports from developed to developing countries totaled 32,802.1 million dollars for the same year. INTERNATIONAL MONETARY FUND, DIRECTION OF TRADE 32 (Annual 1964-1968).

6. Under present trade patterns, developing countries export primary products and raw materials to developed countries (25,370 milkon dollars worth in 1968), and inport chemicals, machinery, and other manufactures needed for industrial development (26,800 million dollars in 1968). 2 STATISTTCAL OfFice OF the UNTTED NatToNs, 
for 63.5 percent of the world's ocean transport trade by volume. ${ }^{7^{-1}}$ Yet the developing countries' merchant shipping fleets comprised only 7.6 percent of the world tonnage in 1969, and this figure represents a declinefrom their 1964 share. $^{8}$ As a result, developing countries must depend upon foreign carriers to ship their exports and imports, and must pay for these services in foreign currency, with attendant balance-of-payments problems. ${ }^{9}$ A cartelized system of liner conferences ${ }^{10}$ that controls the rates charged for liner shipping services throughout the world presently makes amelioration of this situation difficult if not impossible. The developing countries allege that their balance-of-payments and other trade problems are aggravated by a high level of freight rates maintained through the monopolistic power of the conferences. ${ }^{11}$ For this and other reasons, developing countries insisted on the establishment of an international organization - the United Nations Conference on Trade and Development (UNCTAD) - to deal primarily with their special problems of foreign trade and economic development. As a result of UNCTAD actions, a number of programs for dealing with the liner conferences now exist.

This Comment deals with developing-country attempts to control the ratemaking power of the conferences. Part I reviews the history, economic characteristics, and operation of the hiner conference system. Part II discusses the special problems of developing countries vis-á-vis the liner conferences. Part III outlines developing-country efforts to establish within the UNCTAD framework a forum for negotiation and change of the conference system. Part IV examines unilateral attempts

1968 SUPPLEMENT to THE World TRADE ANNUAL xi (1969) [hereinafter cited as SUPPLEMENT].

7. The quantity of world exports transported by sea more than doubled between 1959 and 1968, increasing to a total of 2,050 million metric tons. The 63.5 percent developing-country share of this total in 1968 represents an increase from the 1959 share of 61.4 percent. Review of Maritime Transport, 1969, at 3-4, U.N. Doc. TD/B/C. 4/66 (1969).

8. Id. at 8. These figures, compiled according to flag of registration, exclude ships registered in Panama and Liberia, whose low registration requirements have facilitated the creation of large fleets and whose flags do not reflect ownership by local nationals. One recent study shows that, of the 118 regular shipping lines serving Latin America, only 17 operate under Latin American flags. Maritine Freight Rates in the Foreign Trade of Latin America 13, U.N. Doc. E/CN.12/812 (1969).

9. The reasons for the absence of large developing-country flects are discussed in the text accompanying notes 49-53 infra.

10. Conferences are cartels of shipping lines organized around a basic agreement to restrict or eliminate competition by charging uniform rates, regularizing sailing schedules, and, im some cases, pooling cargo or freight revenues for distribution among the members. Marx 3; The Liner Conference Systein 3-6, U.N. Doc. TD/B/C. 4/62/Rev. 1 (1970). The first conference was formed in 1875 . By 1965 there were approximately 360 different conferences doininating the liner transport system, each limited to shipowners of varymg national flags operating on a single route. Id. at 3 .

11. See Report of the Working Party on Shipping, in 1 Proceedings 219, 221. 
to reform the system and evaluates these methods as possible models for action within UNCTAD.

\section{The Liner Conference System}

The development of efficient and dependable steamships in the second half of the 19th century facilitated the growth of world commerce by providing shippers ${ }^{12}$ with regularly scheduled liner services. ${ }^{13}$ Shipping lines operating regular services soon organized conferences ${ }^{14}$ to avoid the fierce competition which had resulted in rate wars and threatened their trades. ${ }^{15}$ By the early 20 th century, the conferences had increased sufficiently in number and power to command the attention of several governments. ${ }^{16}$ Investigations in Great Britai ${ }^{17}$ and the United States ${ }^{18}$ yielded the same general conclusion: Although shipping conferences dommate world trade and possess a potential for monopoly power, the unique economic characteristics of liner trade require a system of conferences to control competition. ${ }^{19}$

\section{A. Basic Economic Characteristics}

Coinprehension of the conference system must begin with an understanding of certam basic economic primciples of ocean transport. Once a liner has been committed to a specific route and sailing schedule, most transport costs are fixed, since the vessel must travel the specified route regardless of its cargo load. Until the vessel is fully loaded, any additional cargo procured at a price in excess of the marginal cost incurred will help defray this high fixed cost, even though the price is considerably below the average cost of shipment. By refusing to ship cargo at low rates the shipowner faces the possibility of operating ves-

12. The term "shippers" is used throughout this Comment to denote the exporters and importers who purchase shipping space. The terms "shipowner" and "carrier" refer to the operators of liner services.

13. Freight Market and the Level and Structure of Freight Rates 5, U.N. Doc. TD/B/C. 4/38/Rev. 1 (1969) [hereinafter cited as Level and Structure of Freight Rates].

14. See note 10 supra.

15. See text accompanying notes 20-21 infra. See also MARX 260-62.

16. See generally MarX 45-67.

17. Report of the Royal Commission on Shipping Rings, CD. No. 4668 (1909).

18. House Comm. ON the Merchant Marine and Fisheries, Report on Steamship Agreements and Afriliations IN the American and Foreign Domestic Trade, H.R. Doc. No. 805, 63d Cong., 2d Sess. (1914) [hereinafter cited as AleXander COMMITTEE REPORT].

19. See id. at 416-17; Report of the Royal Commission on Shipping Rings, supra note 17, at 78. See generally MARX 50-67. The British report produced no restrictions on conference practices, but the recommendations of the Alexander Committee resulted in the Shipping Act of 1916, ch. 451, 39 Stat. 728, as amended, 46 
sels only partially loaded and must bear the resultant losses. When a route is "overtonnaged,"20 competition will force all carriers to quote below-average-cost rates, rather than lose cargo necessary to meet overhead expenses. Thus, conference supporters claim that without restrictions on competition, prices will fall below costs causing persistent operating losses. Eventually either shipowners will have to be subsidized, or regular service will be curtailed. ${ }^{21}$

\section{B. Operation of the Conference System ${ }^{22}$}

In theory, a conference agreement allows member lines to set rates without fear of being undercut by competitors. Freight rates are set for each conference by consensus of the member hnes, often guided by a permanent ratemaking committee. ${ }^{23}$ Although many rate changes involve across-the-board increases, shippers are rarely consulted before such an mcrease is decided. ${ }^{2 \pm}$ Since most conferences operate in secrecy, closely guarding information concerning the operating costs, profit margins, and tariff lists of their member lines, ${ }^{25}$ successful shippers' challenges to the new rates are exceedingly difficult.

A conference agreement also permits the practice of discriminatory pricing, a rate scheme based on factors other than the actual cost of

U.S.C. $\$ \S 801-42$ (Supp. V, 1970). This Act, still the basic statute governing the commercial aspects of shipping in United States trades, purports to regulate the activities of conferences in return for a grant of immunity from United States antitrust laws. In practice, however, the ratemaking powers of liner conferences lave continued virtually unregulated to the present day. See text accompanying notes 130-63 infra.

20. "Overtonnage" refers to a surplus of cargo space. Such a condition has constantly plagued the liner industry. Level and Structure of Freight Rates 5; D. LOCKLIN, ECONOMICS OF TRANSPORTATION 744 (6th ed. 1966) [hereinafter cited as LockLIN].

21. See, e.g., AleXander Committee Report 416. This argument is coinmonly used to support practices that restrain trade. In the transportation industry it has enjoyed great success, due to the behef that heavy public reliance on transportation requires its special protection. For a criticism of this argument see McGee, Ocean Freight Rate Conferences and the American Merchant Marine, 27 U. CHI. L. REv. 191, 272-279 (1960). For a complete discussion of the economics of high fixed costs in the railroad industry, equally applicable to shipping, see LockLIN 130-57.

22. An excellant and detailed survey of conference practices and operations, based on a study of 27 different trades around the world, is contained in The Liner Conference System, supra note 10. See also McGee, supra note 21, at 205-70.

23. Ocean Shipping and Freight Rates and Developing Countries, in 5 PROceEdnos 212 , at 219. For an informative case study of conference ratemaking procedures, see BeVier, Ratemaking in International Shipping Conferences, 4 STAN. J. INT'L STUDIES 84 (1969).

24. The Liner Conference System, supra note 10, at 29. For a list of developing-country complaints regarding arbitrary increases in rates, see Problems of Shipping and Ocean Freight Rates in the ECAFE Region, in 5 PRoceEdinos 311, 324-330.

25. Shipping and the World Economy, stipra note 4, at 5; Progress Report on the Study of Conference Practices and Adequacy of Shipping Services 7, 9-11, U.N. Doc. TD/B/C. 4/39 (1968). 
the service for a given commodity. By basing prices on the exigencies of demand for transport rather than on the average cost, a carrier can charge relatively high rates on commodities with inelastic demand for transportation, ${ }^{26}$ and low rates for commodities which would not otherwise be shipped. ${ }^{27}$ "Charging what the traffic will bear," as this is called, means in practice that relatively high rates are charged on commodities with a high value-to-weight or value-to-volume ratio, such as manufactured goods, and relatively low rates on cheap, bulk commodities such as raw materials. ${ }^{28}$

Restraint of competition is an essential condition for the practice of discriminatory pricing. ${ }^{29}$ In the conference system, internal competition is regulated by allocating sailing dates and cargo quotas, pooling revenues, and penalizing, with fines or expulsion, meinbers who attempt to undercut the couference rates. ${ }^{30}$ Since rate competition is nonexistent, conference liners compete only in quality of service.

The most important competition that conferences face is external, from tramps and nonconference liners. ${ }^{31}$ To prevent loss of cargo to these coinpetitors, the conferences use various tying arrangements, or contracts wth shippers, that make disloyalty to the conference a costly endeavor. ${ }^{32}$ Depending on the level of demand for transport in a particular trade, the number of outside competitors, and the type of tying arrangeinents used, conferences have been moderately to highly successful im excluding competition.

26. Price elasticity of demand or supply refers to a commodity's sensitivity to change in price. Thus, "price inelastic" denotes a condition in which a large change in price will have a relatively small effect on the amount of service or commodity bought or supplied. The demand for transportation is a derived demand, that is, its elasticity depends upon the elasticities of supply in the exporting country and of demand in the importing country.

27. MARX 307; LOCKIIN 135.

28. This is generally termed "value-of-service pricing." See generally MaRX 307-10; LockIIN 143-49. A commodity's "stowage factor," that is, its weight and bulk, is also important in determining the freight rate, but most bulk goods have low value-to-weight ratios and travel at low rates. For a study of these and other ratestructure determinants in Latin American trade, see Maritime Freight Rates in the Foreign Trade of Latin America, supra note 8, at 10.

29. LoCKIIN 139-40.

30. E. Bennathan \& A. Walters, The Economics of Ocean Freight RATES 30-34 (1969).

31. For a discussion of tramp-liner competition and conference-nonconference conipetition in the United States trades, see MARX 223-38, 186-200.

32. The two principal types of tying arrangements are the dual rate, in which a lower rate is quoted to a shipper who signs an exclusive-patronage contract, and the deferred rebate, in which the shipper receives a percentage rebate three to six inonths after the shipment period has ended, provided he has reinained loyal during the entire period. MaRx 201-22; The Liner Conference System, supra note 10, at 17-23. The latter method is the most effective in reducing competition, and is outlawed by section 14 of the United States Shipping Act of 1916, 46 U.S.C. $\$ 812$ (1964). 


\section{Advantages and Disadvantages of the Conference System}

Supporters of the conference system claim that, besides providing uniform rates to all shippers of the same commodity, conferences assure the rate stability needed for shippers to plan their operations. ${ }^{33}$ Conference rates can be considered stable, however, only when compared to the highly volatile tramp rates that are established competitively. In fact, the conference rates are constantly rising, ${ }^{34}$ a phenoinenon that seems to be due, at least in part, to the monopolistic nature of conferences. ${ }^{35}$ Thus, many shippers complain that relative rate stability is bought at the cost of an unreasonably high rate level, ${ }^{36}$ under conditions that offer no effective alternative.

Frequency and regularity of service are also claimed as an advantage of the conferences' control of competition. ${ }^{37}$ There are three major difficulties with this argument: First, to the extent that there is competition only in quality of service, many countries, especially those in developing areas, are being offered unneeded frequency and regularity of service at too high a price. ${ }^{38}$

Second, when supply (in the form of frequent and regular service) and price are both fixed, the normal fluctuation in demand for transport creates many periods of low demand. When this occurs major surpluses of cargo space result. ${ }^{39}$ As the British Royal Commission pointed out in 1909:

33. Level and Structure of Freight Rates, supra note 13, at 22; REPORT OF THE Royal Commission on SHIPPING RINGS, supra note 17, at 38-39, 48-50.

34. Liner rates, according to statistics of the West German Ministry of Transport, were 53 percent higher in 1967 than in 1954, but the increase came gradually, usually 4 to 5 percent each year. In contrast, trainp rates in 1967 were 19 percent lower than in 1954, but had fluctuated significantly from year to year, shifting as much as 50 percent in one year. Level and Structure of Freight Rates, supra note 13, at 22. See also The Liner Conference System, supra note 13, at 36-37.

35. See McGee, supra note 21, at 292.

36. See Report of the Working Party on Shipping, supra note 11, at 221; Problems of Shipping and Ocean Freight Rates in the ECAFE Region, supra note 24, at 311, 324-27.

37. See, e.g., ALEXANDER COMMTTEE REPORT, supra note 18, at 416.

38. Ocean Shipping and Freight Rates and Developing Countries, supra note 23, at 219,268; Shipping and the World Economy, supra note 4, at 5.

39. See McGee, supra note 21 , at 289 . Unutilized cargo space has been a chronic condition of the liner conference system. In 1950, over three times the quantity of tonnage employed in 1900 was used to carry only about 50 percent inore cargo. Level and Structure of Freight Rates, supra note 13, at 5. See generally MARX 301-02. A reverse trend has developed in recent years; from 1950 to 1965 , international drycargo trade increased 140 percent, and tonnage increased only 88 percent. Review of Developnents in World Shipping 11, U.N. Doc. TD/B/C. 4/25 (1967). Nevertheless, two principal United States conferences still showed an average unused cargo space of 60 and 66 percent from 1962 to 1968. Investigation of Ocean Rate Structures in the Trade Between the United States North Atlantic Ports and Ports in the United Kingdom and Eire, 12 F.M.C. 34, 40-41 (1968). 
[I]t is possible that ships of greater value or tonnage or number than are required may be imposed upon a particular trade, with the result that the rates are higher than they ought to be, though the Shipping Companies may not be earning an inordinate or even a reasonable profit. ${ }^{40}$

Hence, unutilized cargo space is another cost of frequent and regular service.

Third, the achievement of frequent and regular service does not require a cartelized system. The same result is possible in any rational transport scheme, as, for example, a competitive system with government subsidization to ensure the reasonable profits necessary to retain regular service. ${ }^{41}$

The most frequent criticism of the liner conference system alleges that it enables conference shipping lines to earn monopoly profits. Although it is possible to determine the validity of this criticism without access to the conferences' closely guarded profit and cost data, ${ }^{42}$ it is more likely that an influx of new lines lured by set rates, and the preservation of inefficient operators who need not compete in price, waste any monopoly profits that would otherwise exist. ${ }^{43}$ From the shippers' standpoimt, the result is the same: unduly high freight rates.

Critics of the conference system also attack the unilateral method of deciding rate changes, without consultation with shippers. ${ }^{44}$ They question the ability of the conferences to set rates efficiently. For example, a conference faced with rising transport costs will attempt to raise rates on commodities for which the demand will bear an increase, ${ }^{45}$ yet the conferences are ill equipped to analyze the myriad factors which comprise this demand. ${ }^{46}$

Thus, rate stability and frequency and regularity of service, the positive results of conference control of liner services, are not without harmful side effects: a high level of freight rates, inefficiency of operation, and lack of responsiveness to shippers' demands. The negative aspects of the conference system have had a particularly pernicious effect on the developing countries' efforts to expand their trade. The next three parts of this Comment describe the developimg countries' efforts to mitigate these negative effects. ${ }^{47}$

40. REPORT OF THE ROYAL COMMISSION ON SHIPPING RINGS, supra note 17, at 79 .

41. One of the objectives of United States maritime subsidies has been the assurance of regular services. McGee, supra note 21, at 284.

42. See text accompanying note 25 supra.

43. McGee, supra note 21 , at $198-200$.

44. See text accompanying notes 23-25 supra.

45. See note 26 supra and accompanying text.

46. BeVier, supra note 23 , at $99-100$.

47. This Comment does not reject or propose alternatives to the present system. 


\section{Special Problems of Developing Countrues}

Much of the criticism developing countries direct against the conference system resembles the general objections noted above, such as the lack of negotiation in ratemaking and the high level of liner rates. ${ }^{48}$ However, many developing countries also face special problems with ocean transport.

\section{A. Lack of Developing-County Representation Within the Conferences}

Although foreign trade is an important factor in the developing countries' economic growth ${ }^{49}$ and ocean shipping their most important form of transporting this trade,$^{50}$ these countries as a group lack any sizeable merchant shipping fleet. ${ }^{51}$ This is due in part to a lack of available capital in developing countries for investment in capital-intensive industries. $^{52}$ However, for former African and Asian colomies, a primcipal deterrent to the development of large merchant fleets has becn the colonial powers' monopoly over maritime transport, and their active resistance to the colonies' efforts to build merchant marines of their own. ${ }^{.8}$

To the extent that developing countries lack merchant shipping fleets, they also lack effective representation of their interests in the rateniaking processes of the conferences. These countries complain that the liner conference system, which developed according to the needs of developed-country trade in the 19th century, has failed to consider the poorer nations' special needs. ${ }^{54}$ In support of their argument they point to the control of conferences by developed-country interests, ${ }^{55}$ the secrecy in which conferences operate, ${ }^{, 6}$ and the remoteness from develop-

The developing countries themselves have not sought to abolish the conferences. See text accompanying note 87 infra.

48. These and other objections were raised at the 1964 UNCTAD Conference. See Report of the Working Party on Shipping, supra note 11, at 219, 220-23.

49. See note 2 supra and accompanying text. The present trade pattern for developing countries is discussed in note 6 supra.

50. See Report of the Working Party on Shipping, supra note 11, at 219, 220.

51. See note 8 supra and accompanying text.

52. See note 172 infra and accompanying text.

53. N. Singh, ACHIEveMENTS OF UNCTAD-I (1964) AND UNCTAD-II (1968) IN THE Field of SHIPPING AND INVISIBLes 11 (1969).

54. See International Transoceanic Transport and Economic Development 4, 10, U.N. Doc. TD/B/C. 4/46 (1969). See also text accompanying note 38 supra.

55. Developed countries (excluding socialist states) accounted for 58.6 percent of all merchant tonnage in 1969. Review of Maritime Transport, 1969, supra note 7, at 8. Another 17.1 percent was registered under Liberian and Panamanian "flags of convenienee" but owned by developed-country interests. $1 d$.

56. See text accompanying note 25 supra. For example, conference members suggest that high port costs in developing areas account for the high level of rates, 
ing areas of conference headquarters, where the decisions are made. ${ }^{57}$ Without representation as shipowners, and lacking effective bargaining procedures with the conferences, the developing countries receive no assurance that ratemaking decisions, adopted behind closed doors, adequately reflect their overall interests in economic development.

\section{B. The Balance-of-Payments Problem}

Since suppliers of shipping services require payment in their own or a fully convertible currency, freight payments to foreigners are entered as debits in a country's balance of payments. ${ }^{58}$ As purchasers of shipping services, developing countries' entries in this category are quite large. ${ }^{59}$ The effects of this deficit must be viewed in light of the developing countries' deteriorating trade position ${ }^{80}$ since many developed countries also face large freight deficits. ${ }^{61}$ Freight deficits of the latter are usually offset by net credits in their export-import trade or capital accounts, but developing countries face increasing net deficits in this area as well. ${ }^{62}$ Their poor initial position is thus aggravated by declining commodity prices-their primcipal source of export income-and rising freight rates. ${ }^{63}$ In the long run, a developing country must change its

but the lack of information made available on factors that determine rate level and structure makes it impossible to check this assertion. In addition, very little is known of conference power structures and decisionmaking processes themselves. Maritime Freight Rates in the Foreign Trade of Latin America, supra note 8, at 16, 17. In some instances, lack of access to complete tariff lists makes allegations of discrimination among shippers difficult to substantiate. The Liner Conference Systein, supra note 10, at 27-28. An exception occurs in United States trades, since the Shipping Act of 1916 requires that all tariffs be filed and open to public inspection. 46 U.S.C. $\$ 817$ (b)(1) (Supp. V, 1970), amending 46 U.S.C. $\$ 817$ (b)(1) (1964).

57. Even in developing-country trades, most conference headquarters are located in developed countries outside of the region. The Liner Conference System, supra note 10, at 9; Maritime Freight Rates in the Foreign Trade of Latin America, supra note 8 , at $49-50$.

58. SöDERSTEN, supra note 1 , at 227.

59. In 1961 alone, the total developing-country net deficit for freight amounted to 1,884 million dollars. This includes payments for all means of transport, although ocean shipping is the major item. Ocean Shipping and Freight Rates and Developing Countries, supra note 23, at 231-33.

60. Developing countries, for which primary products account for roughly 80 percent of exports (but only 30 percent of developed-country exports), face the problem of static primary-commodity prices with rising prices for the manufactured goods that they import. 2 WORLD TRADE ANNUAL, supra note 3 , at xii.

61. The United States is an important ocean-freight purchaser, with a net freight deficit of 496 million dollars in 1968. 21 InTERnational MONETARY Fund, BaLANCE of Payments Yearbook 2 (1970).

62. In trade with developed countries, developing countries had an export deficit of 1,690 million dollars in 1968, compared with a surplus of 450 million dollars in 1955. 2 SUPPLEMENT, supra note 6, at xi. (1967).

63. Review of Developments in World Shipping 15-26, U.N. Doc. TD/B/C. 4/25 
economic policy-import less or export more-or else face a situation in which foreign reserves are depleted and loans of capital increasingly hard to obtain. ${ }^{64}$

\section{The Effect of Freight Rates on Exports}

Normally, it is the freight paid to foreign carriers on imports that enters into a country's balance of payinents, since the importer usually bears the cost of transport. ${ }^{65}$ However, the level and structure of freight rates are also important to the developing countries' export trade, although their effects are not so well understood.

Developing countries are highly dependent on the export of priinary products, ${ }^{68}$ of which freight charges represent a sizeable share of total cost. ${ }^{67}$ For such products, even small fluctuations in rates will have a strong effect on their competitive position in the import inarket. Thus, an increase in freight rates has an important detrimental effect on the producing country and its economy. ${ }^{68}$ In an extreme case, it can even nullify a country's competitive advantage in a product. ${ }^{60}$ In this way, freight rates liave protective effects much the same as tariffs imposed by the importing country. ${ }^{70}$ Part of this protection is inevitable, due to the distance between developing-country producers and the mar-

64. See SöDERSTEN, supra note 1, at 233-40.

65. Ocean Shipping and Freight Rates and Developing Countries, supra note 23, at 223 .

66. See note 6 supra.

67. While the shipping rate per ton is low on bulk goods such as grains, ores, and other primary products, the value per ton of the cominodity shipped is also low (compared to that of inanufactured goods), thus making the freight charge an important percentage of total cost under value-of-service pricing. See note 28 supra and accompanying text.

68. "The actual magnitude of this inpact would depend on the elasticities of demand and supply in the countries of export and import." Review of Maritime Transport, 1969, supra note 7, at 27. Thus, the formation of a liner conference may distort the export trade of a small country faced with inelastic supply and a competitive market by keeping rates at a high level. In such a case, an increase in freight rates will either price producers out of the market or reduce their revenues. $E$. Bennathan \& A. Walters, supra note 30, at 25-26; A. Koch, Current Pricing BeBAVIOUR IN LINER SHIPPING 17-29 (1968). For an example of the importance of elasticities and freight rates in the natural-rubber trade, see The Maritine Transportation of Natural Rubber 68-77, U.N. Doc. TD/B/C. 4/60/Rev. 1 (1970).

More subtle and as yet unstudied is the effect that conferences' value-of-service pricing has on the tendeucy of industries to locate near the developed-country markets. This market orientation of industry is enhanced when raw materials can be imported at a relatively low transport cost added to the price of the product at point of origin. See generally C. Kindleberoer, INTERnational EConomics 86-101 (4th ed. 1968).

69. Ocean Shipping and Freight Rates and Developing Countries, supra note 23, at 258 .

70. See generally Level and Structure of Freight Rates, supra note 13, at 77-81. For a general discussion of tariff effects see C. KINDLRBERoER, supra note 68, at 105-29. 
kets of Europe and the United States. However, the method of rate formation in the liner conference system sets this tariff-like barrier artificially, according to what the traffic will bear, with no assurance that it corresponds to the best interests of the country's economic development. ${ }^{71}$ Moreover, unlike customs duties, rate tariffs are imposed by conferences without fear of retaliation or political pressure-methods that can be used to influence the protective tendencies of governments.

\section{III}

\section{INTERnational AtTEMPts to Deal With an International Problem}

This laissez faire situation is beginning to change as the developing countries, lacking individual strength, have begun putting collective pressure on the governments of maritime powers to change the conference systein, through the forum provided by UNCTAD. While not rejecting the conference system per se, these countries hope that, within UNCTAD, they can at least remove its veil of secrecy and inject consideration of their special problents into the ratemaking process.

\section{A. Background}

A number of international, mostly nongovernmental, organizations have demonstrated competence in the field of shipping. ${ }^{72}$ None of them, however, has ever challenged the shipping conferences' ratemaking powers. ${ }^{73}$ Until the founding of UNCTAD's Committee on Shipping, ${ }^{74}$ the only international organization conipetent to deal with

71. For example, an important topic at the first UNCTAD Conference in 1964 was whether promotional freight rates should be instituted in order to encourage developing-country exports. The developing countries alleged that the growth of their export trades had been impeded by the present rate structure. Report of the Working Party on Shipping, supra note 11, at 221.

72. The International Maritime Committee (IMC), with headquarters in Brussels, was founded in 1897 for the purpose of sponsoring the unification of international maritime law and practice. Conventions sponsored by the IMC have dealt with the law of collisions at sea, salvage, maritime mortgages, and bills of lading. The International Labour Organization's Joint Maritime Committee is concerned with protecting the rights of maritime workers. The International Law Commission (ILC) is devoted to public maritime law. For a discussion of the activities of the IMC and other organizations, see Thommen, International Legislation on Shipping 25-29, U.N. Doc. TD/32/Rev. 1 (1968).

73. In 1948, the Sea Transport Committee of the International Chamber of Commerce (ICC) expressly decided against interference in conference rate matters by agreeing that the ICC should not becoine involved in shipper-slipowner controversies. MARX, supra note 4 , at 272 u.10. Nor have the contracting parties to the General Agreement on Tariffs and Trade (GATT) concerned themselves collectively with shipping problems. K.W. DaM, The GATT: LAW and INTERnational Economic ORGANIZATION 383 (1970).

74. See text accompanying notes $95-98$ infra. 
such matters was the United Nations' Intergovernmental Maritime Consultative Organization (IMCO), which derived from the various agencies used to coordinate allied shipping activities in World War II. A wholly advisory body, IMCO's charter included among its purposes "[t]o provide for the consideration by the Organization of matters concerning unfair restrictive practices by shipping concerns ...." In In practice, IMCO has concerned itself almost exclusively with questions of maritime safety and technical matters, eschewing the opportunity to involve itself with conferences' ratemaking practices. ${ }^{78}$ This is probably due to the control of IMCO's principal decisionmaking body, the Council, by the powerful shipowning nations. ${ }^{77}$

The failure of international organizations to consider the commercial and economic aspects of ocean transport, coupled with developing-country frustration in dealing with the conferences, created a propitious chinuate for the creation of an international organization that would seriously question the conference system. For aid in this endeavor, the developing countries turned to the United Nations, which, by the early 1960 's, had begun to reflect some important changes in the relations between developed and developing countries. Developing countries had recognized that, even with much-publicized foreign aid from developed countries, their position as a group in world trade was constantly deteriorating. ${ }^{78}$ In addition, there was a growing behef within the developing countries that the developed countries were keeping the consideration of sensitive trade matters within international organizations they dominated, such as the GATT, the International Bank for Reconstruction and Development (IBRD), the International Monetary Fund (IMF), and the International Development Association (IDA). ${ }^{70}$ Finally, the inclusion of former colonies as independent states in the United Nations had greatly increased the number of developing countries relative to developed countries. This enabled the developing countries to pass resolutions in the General Assembly ${ }^{80}$ and the Economic and

75. Unted Nations Maritime Conference, final act and Related DocuMENTS 29 (1948). See generally MARX 272-79.

76. See Review of Studies and Activities in the Field of Shipping and Ports 23, U.N. Doc. TD/B/C. 4/26 (1967).

77. MARX 277.

78. Gosovic, UNCTAD: North-South Encounter, 568 INT'L CoNCILIATION 5, 6 (1968). See also notes 60,62 supra.

79. Id. at 10. There was, at the same time, disenchantment with the existing United Nations forums due to developed-country failure to participate actively in the Economic and Social Council (ECOSOC) and the Economic and Financial Committee of the General Assembly. Gardner, The United Nations Conference on Trade and Development, 22 INT'L ORGANIZATION 99, 100 (1968).

80. G.A. Res. 1707, 16 U.N. GAOR, Supp. 17, at 14, U.N. Doc. A/5100 (1961). 
Social Council ${ }^{81}$ that led to the convening of the international economic conference to discuss trade problems and their effect on development.

\section{B. The UNCTAD Conference of 1964: Establishment of the Committee on Shipping}

One hundred and twenty states attended the first Umited Nations Conference on Trade and Development, held at Geneva in the spring of 1964. Most fundamentally, the conference stressed the need for measures to increase the trade of developing countries, including a "reappraisal of the effectiveness of the existing international bodies dealing with international trade im meeting trade problems of developing countries." ${ }^{2}$ Although shipping-conference practices and freight rates had traditionally been forbidden subjects at intergovernmental meetings, ${ }^{83}$ the agenda approved for the conference included consideration of "[m]easures for improving the invisible trade of developing countries through . . . reducing payments for transportation . . . ."84 As a result, the Working Party on Shipping was established to consider, among other subjects, problems of transport costs, the structure of freight rates, the functioning of the liner conference system, and discriminatory arrangements in shipping. ${ }^{85}$

The debates that took place within the Working Party illustrate the differences of opinion between developed and developing countries over issues of ocean transport and the conference system..$^{86}$ While both sides generally agreed that the conference system is necessary, the developed countries defended the conferences' freedom from interference by governments or intergovernmental bodies agamst developingcountry allegations that such interference was necessary to reverse their own inordinate dependence on developed maritime nations and to reforn conference practices that adversely affected their foreign trades. ${ }^{87}$

Rather than gradually arriving at an agreement, the two groups split into rigid blocks-thus beginning what has become characteristic both of UNCTAD institutions and conferences ${ }^{88}$ - and produced two

81. ECOSOC Res. 917, 34 U.N. ECOSOC, Supp. 1, at 7, U.N. Doc. E/3671 (1962).

82. G.A. Res. 1785, 17 U.N. GAOR, Supp. 17, at 14, U.N. Doc. A/5217 (1963). See generally Report of the Conference, in 1 Proceedings, supra note 2, at 101.

83. Gosovic, supra note 78, at 62; MARX 270.

84. Report of the Conference, supra note 82 , at 105. This item had been stressed in the earlier Joint Declaration of the Developing Countries Made at the Eighteenth Session of the General Assembly, G.A. Res. 1897, 18 U.N. GAOR, Supp. 15, at 24, 25, U.N. Doc. A/5515 (1964).

85. Report of the Working Party on Shipping, supra note 11, at 219.

86. See id. at 219-29.

87. Id. at 220 .

88. Gosovic, supra uote 78, at 14-30. The "Group of 77," a coalition of de- 
separate draft recommendations. ${ }^{80}$ Although unable to reach agreement on either, the Working Party finally approved a "Common Measure of Understanding on Shipping Questions," which eventually became Recommendation A.IV:22 and was adopted by the full Conference without dissent. $^{00}$ The Common Measure reiterated the need for a liner conference system, but went on to recommend that "a well-organized consultation machinery ... be established, with adequate procedures for hearing and remedying complaints, by the formation of shippers' councils or other suitable bodies on a national and regional basis." the many sensitive topics suggested as proper matters for consideration within the consultation machinery ${ }^{22}$ were publication of conference tariffs and regulations, increases in conference freight rates, the terms of all tying arrangements, and representation of conferences in developing-country ports. ${ }^{03}$ Although the recommendation had no binding effect on the states participating in the Conference, it was an important accomplishinent for the developing countries, since it represented the first multilateral recognition by developed as well as developing countries of the need for changes in the liner conference system..$^{04}$

More important was the resolution that recommended the establishment of an intergovernmental committee to study and report on economic aspects of shipping as part of any future permanent organization. ${ }^{05}$ The Conference further recommended that the organization give

veloping countries, has endured as a political unit within UNCTAD and continues to serve as a focal point for developed-country distrust of an organization they believe to be dominated by the developing nations.

89. Sponsored by Sweden, the developed-country draft recoinmended that, since free competition between shipowners ensures efficiency, "[n]o measures should . . . bc taken that impede this freedom." Report of the Working Party on Shipping, supra note 11, at 226. The resolution did recominend increased consultations between shippers and shipowners, but without any aspects of governinent control. Id. The developing-country draft recommended, among other things, that "[a]n appropriate international machinery on an inter-governmental level should be established under the United Nations to tackle inatters of maritime transport and ocean freight rates on a global basis." Id. at 223. It went on to request an claborate consultation machinery, with an active role to be played by governinents; specific guidelines for such conference practices as publication of tariffs, revision of tying arrangements, and adequate conference representation in developing-country ports; promotional rates for developingcountry exports; and financial assistance for port inprovenents and expansion of developing-country inerchant marines. $I d$. at 224.

90. Final Act, in 1 Proceedings 3, 54; Annex F-Report of the Third Committee, in id. at 169, 228-29.

91. Final Act, in 1 Proceedings 3, 54.

92. "Consultation machinery" refers to a method of shipper-shipowner negotiation in which the former are associated into bargaining units known as "shippers' councils." See Consultation in Shipping 1, U.N. Doc. TD/B/C. 4/20/Rev. 1 (1967). See also text accompanying notes 189-214 infra.

93. Final Act, in 1 Proceedings 3, 54.

94. SingH, supra note 53 , at $64-67$.

95. Recommendation A.IV.21, Final Act, im 1 Procerdings 3, 54. Whether the 
"special consideration to the appropriate institutional means for dealing with problems of shipping," taking into account the suggestions contained in the Common Measure. ${ }^{96}$ This stateinent was reiterated in the General Assembly resolution that formally established UNCTAD, ${ }^{97}$ and resulted in the establishment by the Trade and Development Board of a permanent Committee on Shipping. ${ }^{98}$

Although the Committee on Shipping has contributed inore as a study unit than as a lawinaking institution, ${ }^{99}$ the importance of its establishment should not be underestimated. The developing countries, individually lacking the economic and political size and influence to deal effectively with the conferences, have used the Committee on Shipping and the UNCTAD Conferences to apply political pressure on governments to effect changes in the liner conference system. In addition, the Coinmittee's establishment as a permanent body has meant that important shipping matters, unstudied by other international organizations, are subject to continuous study and informed discussion in an effort to formulate a general policy toward the conferences.

\section{Operation of the Committee on Shipping}

The terms of reference of the Committee on Shipping directed it, among other thimgs, to promote negotiation between shippers and shipowners; to study and make recommendations on economic aspects of shipping, especially those aspects which affect the trade and balance of payments of developing countries; and to promote action on national, regional, and intergovernmental levels to deal with problems of shipping. ${ }^{100}$ The Committee, composed of the representatives of 45 na-

Conference should retain its ad hoc character was a major subject of debate. The developing countries, arguing that the present institutions did not adequately consider their special trade problems, urged the establishment of a new and permanent international trade organization. On the other hand, the developed countries dishiked the idea of submitting important trade questions to a one-nation-one-vote foruin controlled by a developing-state majority. Eventually, the developing countries prevailed, and the Conference recoinmended UNCTAD's estabhishment as an organ of the General Assembly, with a permanent Trade and Development Board of $55 \mathrm{mem}$ bers, a Secretariat to service the Board and Committees, and a triennial Conference. Recoininendation A.V.1, id. at 58-62. See generally Gosovic, supra note 78, at 9-13; Cordovez, The Making of UNCTAD, 1 J. WORLD TRADE L. 243, 281-307 (1967).

96. Recommendation A.V.1, Final Act, in 1 Proceedings 3, 58-59.

97. G.A. Res. 1995, 19 U.N. GAOR, Supp. 15, at 1, 3, U.N. Doc. A/5815 (1965).

98. Resolution 11 (I), Trade and Development Board Official Records, First Session: Resolutions and Decisions 1, U.N. Doc. TD/B/70 (1965).

99. See text accompanying notes 100-06 and 121-25 infra.

100. Decision 12 (I), Trade and Development Board Official Records, First Session: Resolutions and Decisions, supra note 98, at 5-6. 
tions, ${ }^{101}$ meets once a year. The Shipping Branch, a research seetion in the Division for Invisibles of the UNCTAD secretariat, ${ }^{102}$ provides the Committee with information concerning the level and structure of freight rates, conference practices, and other subjects. These same studies are published by the United Nations and distributed throughout the world, in an attempt to remove some of the secrecy and lack of understanding that surrounds the conference system. ${ }^{103}$

Resolutions passed by the Committee are only recommendatory; they do not bind the meinber governments to any specific action. For the most part, these resolutions consist of authorizations to the UNCTAD Secretariat to conduct particular studies, ${ }^{104}$ and recommendations of general shipping policies ${ }^{105}$ to the member governments. Thus, as presently constituted, the Committee should be viewed as a forum for discussion rather than an instrument for negotiation leading to specific nuultilateral action. The possibility of the Committee's successfully assuming the latter role is the subject of a later section. ${ }^{108}$

\section{The UNCTAD Conference of 1968}

The second UNCTAD Conference (UNCTAD-II) convened in New Delhi in 1968. ${ }^{107}$ The developing countries had made active preparations for the Conference, hoping that negotiations would lead to substantive changes in the world trade systen,, including changes in the ratemaking procedures of the liner conferences. ${ }^{108}$ On the whole, UNCTAD-II failed to produce these substantive changes since the developed states, overwhelned by the range of the developing countries'

101. For a list of member countries, see Report of the Committee on Shipping on its Fourth Session 32, U.N. Doc. TD/B/301 (1970).

102. Activities of UNCTAD in the Field of Shipping 4, U.N. Doc. TD/B/C. 4/27 (1967).

103. UNCTAD studies are not, of course, limited to liner conferences, but cover all economic aspects of shipping.

104. E.g., Resolution 12 (IV)(I), Report of the Committee on Shipping on its Fourth Session, supra note 101, at 22-23; Resolution 14 (IV), id. at 24.

105. E.g., Resolutions 11 (IV), 12 (IV) (II), 13 (IV), id. at 22, 23-24.

106. See text accompanyimg notes 121-25 infra.

107. Normally the conferences are to be lield every three years. See note 95 supra.

108. See Erb, The Second Session of UNCTAD, 2 J. World Trade L. 346, 346-52 (1968). Regional meetings leeld in Asia, Africa, and Latin America produced declarations reiterating developing-country demands made at Geneva in 1964 [see note 89 supra]. The Bangkok Declaration of the Ministerial Meeting of ECAFE Developing Countries, Group of 77 Doc. MM/77/I/Misc. 3; The Charter of Tequendama, Group of 77 Doc. MM/77/I/Misc. 7; African Declaration of Algiers, Group of 77 Doc. $M M / 77 / 1 / M i s c$. 9. Then, in October of 1967, representatives of the Group of 77 [see note 88 supra] met at Algiers and issued a further statement of these same demands. Charter of Algiers 18-20, U.N. Doc. TD/38 (1967). Although the developing countries hoped that the New Delhi Conference would see UNCTAD graduate from the level of a vent for their complaints to a forum for negotiation 
demands, refused to be pressured into binding obligations. ${ }^{109}$ In the area of shipping, however, some significant advances occurred. For the first time, unanimous resolutions were passed specifically recommending that the member governments approach the conferences in order to establish consultation machinery ${ }^{110}$ and actively lobby with the conferences to reduce rate levels, provide promotional freight rates for developing-country products, and make other concessions. ${ }^{111}$ While not legally binding, these resolutions represented a further advancement of opinion against unregulated liner conferences, and recognized the need for involving governments in the process. ${ }^{112}$

Of greater long-range importance for any ultimate revision of the liner conference system was Conference Resolution 14 (II), ${ }^{113}$ which authorized the establishment of a Working Group on International Shipping Legislation to "review commercial and economic aspects of international legislation on shipping in order to identify areas where modifications are needed and to give recommendations concerning new legislation which has to be drafted."114 The mclusion of this item in the agenda for UNCTAD-II had been sharply debated within the Committee on Shipping. The developed countries had opposed it on the ground that other organizations, including the IMC, IMCO, and the newly formed United Nations Commission on International Trade Law (UNCITRAL) already covered the field. ${ }^{115}$ The developing countries replied that existing maritime law reflected the obsolete attitudes of maritime nations and shipowners and that there would be no conflict with other agencies since they had not studied matters of international legislation dealing with conference practices and the special problems of developing countries. ${ }^{116}$

towards international agreeinent, the "shopping list" of demands seemed to increase developed-couutry distrust for UNCTAD as a center for negotiation. Erb, supra at $346-47,351$.

109. For a statemeut of the general developing-country disappointment with the outcome of the Conference, see A.F. Azevedo da Silveira, Declaration Relating to Issues of Developmeut Financing, U.N. Doc. TD/92 (1968).

110. Resolution 2 (II), in 1 Proceedings of the UNITED Nations CONFERENCE on Trade and Development, Second Session, Annex I, at 27, 45, U.N. Doc. TD/97 (1968) [hereinafter cited as ProceEdnas (II)].

111. Resolution 3 (II), id., Annex I, at 27, 46.

112. Reporting on the achievennents of UNCTAD-II in the field of shipping, The Economist of London observed that such government involvenent in shippershipowner negotiation "now threatens a generalisation of this practice throughout the developing world, which would put another nail in the coffin of the shipping lines' long-defended laisser faire principles." THE ECONOMST, Apr. 6, 1968, at 65.

113. Resolution 14 (II), in 1 ProceEdings (II), Annex I, at 27, 50.

114. Id. at 51.

115. Report of the Committee on Shipping on its Second Session 15, U.N. Doc. TD/B/116/Rev. 1 (1967).

116. Id. For a list of activities carried on by existing international maritime 
The item on international shipping legislation was finally included, but the developed-developing country split was never resolved. ResoIution 14 (II) was finally passed solely by the votes of the developing countries. ${ }^{117}$ The resolution directed three areas of initial study for the Working Group-rules regarding charter parties for tramp ships, marine imsurance, and possible revision of rules regarding bills of lading $^{118}$ - but left open its long-term objectives. ${ }^{110}$ Given the attention that UNCTAD has paid to ratemaking problems and the conference system, it is conceivable that an attempt will eventually be made to sponsor international agreements on ratemaking practiccs of conferences. In doing so, UNCTAD will further extend itself into areas that fall within the jurisdiction of other international agencies, such as IMCO and UNCITRAL, that have failed to question conference practices. ${ }^{120}$

As yet no substantive developments have emerged from the deliberations of the Working Group. Established against the wishes of the developed countries, this new venture represents a challenge to their ability to monopolize this area of international law, and the success of the challenge depends upon UNCTAD's competence as a negotiating body.

\section{E. UNCTAD and the Liner Conferences-Summary}

The UNCTAD Committee on Shipping was founded to question the basic assumptions of the ocean transport system in an atmosphere that the developing countries hoped would be conducive to change. However, after all the debates, resolutions, and studies indicating the

organizations see Thommen, supra note 72, at 21-30. In fact, UNCITRAL, which is capable of considering developing-country problems, failed at its first session in 1968 to include questions of shipping law in its list of priorities. Consideration of Inclusion of International Shipping Legislation among the Priority Topics in the Work Programme 1, U.N. Doc. A/C. 9/23, Annex I (1969).

117. The roll-call vote showed 73 developing countries and socialist states in favor, 19 developed countries opposed, and 5 abstentions. 1 Procendings (II), Annex $\mathrm{I}$, at $27,50-51 \mathrm{n} .80$.

118. Id. at 51. The choice of these priority items seems due to an effort to include subjects that clearly fall within the competence of a trade and development organization, and to conserve the Working Group's effectiveness by considering one portion of the field of shipping law at a time. Smid, International Legislation on Shipping, 3 J. WORLD TRADE L. 318, 326 (1969).

119. The Working Group is to consider "the feasibility of drafting a general instrument (convention or agreement) on maritime transportation and development, dealing with international relations in shipping, for the consideration by an international conference to be convened under the auspices of the United Nations." 1 Proceedings (II), Annex I, at 27, 51.

120. An attempt has been made to coordinate activities with UNCITRAL. Resolution 14 (II) merely directed the Working Group to study legislation regarding shipping and to make suggestions, leaving the drafting of new conventions to UNCITRAL. Only "[i]f it should appear that UNCITRAL is not able to draft the required legislation," would the Committee on Shipping consider other means of drafting 
need for revision of the liner conference system, substantive change has not taken place. In order for UNCTAD to foster change on a multilateral level, through international agreement, its acceptance by developed countries as a forum for serious negotiations on shipping and other trade questions is essential. This acceptance likewise has not come about. ${ }^{121}$ Instead, the developed countries, feeling that as the largest traders they will be the most affected by any change in present practices, are reluctant to bind themselves by decisions of UNCTAD, in which the developing states' voting block prevails against them on important issues. ${ }^{122}$ They continue to treat UNCTAD as merely a vent for developing-country dissatisfaction over current trade patterns.

It does not follow from the paucity of substantive changes, however, that UNCTAD and the Committee on Shipping have had no effect on the attitudes of mdividual nations and other international agencies regarding the need for changes in the ocean transport system. UNCITRAL, for example, was influenced to change its list of priorities to include problems of international shipping legislation. ${ }^{123}$ Moreover, other institutions, seeing UNCTAD's inexorable movement toward changes in the liner conference system and intrusion into their jurisdictions, may cooperate by altering their own laissez faire attitudes toward the liner conferences. ${ }^{124}$

Whatever international framework evolves to promote changes in the liner conference system, one thing is certain: major changes will

it. Id. The UNCTAD Working Group was established in 1969 by resolution of the Committee on Shipping. Report of the Committee on Shipping on its Third Session 13-14, U.N. Doc. TD/B/240 (1969). Soon thereafter, UNCITRAL, at its second session, resolved to include international shipping legislation among the priority items in its work program, and established its own Working Group ou the subject. 24 U.N. GAOR, Supp. 18, at 32-34, U.N. Doc. A/7618 (1969). Coordination at the Secretariat level was achieved through the formation of an UNCTAD/Office of Legal Affairs Joint Shipping Legislation Unit. Report of the Working Group on International Shipping Legislation on its First Session 10-11, U.N. Doc. TD/B/289 (1969).

121. E.g., what was until recently the one major opportunity for UNCTAD to accomplish specific objectives through negotiation, the 1966 United Nations Cocoa Conference sponsored by the Comınittee on Coinmodities to secure stable prices, ended in failure. K.W. DAM, supra note 73, at 379-80. Lately, however, significant progress has been achieved in the negotiations over a generalized scheme of tariff preferences first proposed at the UNCTAD Conference of 1964. See Krishnamurti, The Agreement on Preferences, 5 J. WORLD TRADE L. 45 (1971).

122. See, for example, note 117 supra and accompanying text. For a criticism of UNCTAD pressure-group politics, where differences of opinion are emphasized in group voting, see K.W. DAM, supra note 73, at 379-80.

123. See note 120 supra. Analogously, the establishment of UNCTAD seems to have had a profound effect on the contracting parties to the GATT, causing amendment of the General Agreement to deal with the special problems of developing countries. See Espiell, The Most-Favoured-Nation Clause, 5 J. World Trade L. 29, 33, 38 (1971).

124. K.W. DAM, supra note 73 , at 377 ; Gardner, supra note 79 , at 123-24. 
not occur instantaneously. Most countries still espouse laissez faire policies with respect to the commercial practices of conferences-policies based on 19t1-century principles of freedom of the seas and nondiscriminatory treatment of foreign-flag vessels that have been extended to shield the conferences froin governmental regulation. ${ }^{125}$

Nevertheless, national attitudes toward the liner conferences are changing among the developing countries. UNCTAD's present role is to aid governments in search of policies and programs to control the conferences, through the strength of its recommendatory resolutions and its increasing expertise in the field. Thus, by promoting the adoption of parallel national policies among its member states, UNCTAD may be able to alter the ratemaking powers of the conferences even without achieving specific agreement in the form of a multilateral convention.

\section{IV}

\section{NATIONAL LEgisLation AND THE LINER CONFERENCES}

In the past, three principal policies have been followed by national governments in attempting to deal with the liner conferences on a unilateral level: direct rate regulation, development of merchant marines, and establishment of negotiation procedures. In the next three sections each is evaluated as a possible general poicy for adoption by the developing countries within UNCTAD. Although each policy has distimct drawbacks, the establishment of consultation inachinery, through the use of shippers' councils, offers the best alternative for the developing countries.

\section{A. Direct Rate Regulation ${ }^{126}$}

\section{The United States' Experience}

The government of the United States has made the most concerted effort to directly regulate liner rates in imternational commerce. Thus, an examination of the effectiveness of this effort is useful for the evaluation of direct rate regulation as a general policy for developing countries.

Regulation of liner conferences by the United States is based on the

UNCTAD's Committee on Shipping could benefit by developing increased joint participation with other international organizations such as the GATT. Endowed with developed-country confidence and a long history of negotiation on difficult trade matters, the GATT may be more able to implement solutions to the problems discussed withim the Committee on Shipping. K.W. DAM, supra note 73, at 379-80. For a brief discussion of present GATT-UNCTAD ties, see Espiell, supra note 123, at 33.

125. MARX, supra note 4, at 268. An exception, at least in theory, is the policy of the United States. See text accompanying notes 126-58 infra.

126. "Direct rate regulation" refers to the ability to fix, approve, or disapprove rates charged by a carrier. 
Shipping Act of $1916,{ }^{127}$ enacted during a period of antitrust fervor. Prior to its passage, several courts had held the Sherman Antitrust Act ${ }^{\mathbf{1 2 8}}$ applicable to the restrictive practices of shipping conferences, even though the conferences acted beyond the strict territorial limits of the United States. ${ }^{129}$ Prodded by these decisions and by the report of the Alexander Committee, ${ }^{130}$ Congress enacted the Shipping Act and gave the conferences immunity from the antitrust laws in exchange for direct regulation by a United States federal agency. ${ }^{131}$

The Act requires the filing of all conference agreenents with the Federal Maritime Commission (FMC), which has the authority to "disapprove, cancel or modify any agreement . . . that it finds to be unjustly discriminatory or unfair . . . or to operate to the detriment of the commerce of the United States . . .."132 Certain abusive conference practices, such as deferred rebates, are explicitly forbidden, ${ }^{133}$ but others, such as dual rate contracts, ${ }^{134}$ are permitted under certain conditions. ${ }^{135}$ Sections 16 and 17 of the $A C T^{136}$ confer upon the agency power to reg-

127. Ch. 451,39 Stat. 728 , as amended, 46 U.S.C. $\$ \$ 801-42$ (Supp. V, 1970). This Act has served as the prototype for direct rate regulation by other developed countries. See, for example, the proposed Canadian Legislation-Bill C-184: Shipping Conferences Exeinption Act-reproduced in U.N. Doc. TD/B/C. 4/71 (1970).

128. 15 U.S.C. $\$ \S 1-7$ (1964).

129. See Lowenfeld, "To Have One's Cake . . .--The Federal Maritime Commission and the Conferences, 1 J. Maritime L. \& CoM. 21, 26, 26 n.16 (1969) and cases cited therein.

130. See notes 16-19 supra and accompanying text.

131. Originally called the United States Shipping Board, the agency has undergone a series of reorganizations culminating in the present Federal Maritime Commission. Note, Rate Regulation in Ocean Shipping, 78 HARv. L. REV. 635, 639-40 n.30 (1965).

132. 46 U.S.C. $\$ 814$ (1964).

133. 46 U.S.C. $\$ 812$ (1964).

134. See note 32 supra.

135. Dual rate contracts were allowed until 1958, when the Supreme Court, in Fcderal Maritime Bd. v. Isbrandtsen Co., 356 U.S. 481 (1958), held that such tying arrangements violated section 14 of the existing Act [Shipping Act of 1916, ch. 451, $\S 14,39$ Stat. 728 , as amended, 46 U.S.C. $\$ 812$ (1964)]. This decision set off a new series of congressional investigations. See REPORT OF THE HOUSE COMM. ON Merchant Marines and Fisheries [the Bonner Committee], H.R. ReP. No. 498, 87th Cong., 1st Sess. (1961); ANTTrRust SUBCOMM. OF THE HOUSE CoMM. ON THE JUdICIARY [the Celler Committee], The Ocean Freight INdustry, H.R. Rep. No. 1419, 87th Cong., 2d Sess. (1962). See generally Lowenfeld, supra note 129, at 34-40. The result was a 1961 amendment to the Act which, in effect, reversed the Isbrandtsen decision, allowing dual rate agreements that meet certain guidelines. Act of Oct. 3, 1961, Pub. L. No. 87-346, $\$ 1,75$ Stat. 762, amending 46 U.S.C. $\$ 813$ (1958). These guidelines include a stipulation that the contract not be "detrimental to the commerce of the United States or contrary to the public interest," as well as provisos against rate increases within 90 days after the dual rate contract becones effective, against penalties exacted from shippers who terminate the contract after 90 days' notice to the conference, and against contract rates that are more than 15 percent lower than the ordinary conference rates for the same commodities. 46 U.S.C. $\$ 813 a$ (1964).

136. 46 U.S.C. $\$ \S 815-16$ (1964). 
ulate conference rates directly. Aimed at unjustly preferential or discriminatory treatment among shippers, they contain provisions for criminal fines and alterations of unjust rates. In addition, the 1961 amendment to the Shipping Act added a new section, 18(b), giving the Commission authority to disapprove rates found to be "so unreasonably high or low as to be detrimental to the cominerce of the United States,"137 and requiring filing with the Commission of all freight tariffs in foreign coinmerce. ${ }^{138}$ Disapproval of a particular rate under this section means that its continued use is unlawful ${ }^{139}$ and renders the conference hable for fines up to 1,000 dollars per day. ${ }^{140}$

While in theory the Shipping Act bestows broad rate-regulation powers upon the Commission, in practice these powers have rarely been asserted. ${ }^{141}$ However, in the early 1960's, under congressional attack ${ }^{142}$ and armed with the amended Shipping Act, a revitalized Federal Maritime Commission ${ }^{143}$ launched a series of 18 (b) (5) rate mvestigations, including the NAUK ${ }^{144}$ Investigation into alleged disparities between inbound and outbound rates between the United States and Western Europe. ${ }^{145}$ In pursuing its investigations, the FMC required information on freight revenues, expenses, and profits that could only be obtamed from the conferences and issued orders to the appropriate conferences and shipping lines to produce the relevant documents. ${ }^{140}$ Since many of the conference headquarters and shipping lines are foreign based, the shipowners appealed to their own governments to oppose this uni-

137. 46 U.S.C. $\S 817(b)(5)$ (1964).

138. 46 U.S.C. $\& 817$ (b)(1) (Supp. V, 1970).

139. 46 U.S.C. $\$ 817(\mathrm{~b})(4)$ (1964). Presumably, the conference is therefore precluded from collecting upon that rate.

140. 46 U.S.C. $\& 817$ (b) (6) (1964).

141. Lowenfeld, supra note 129, at 23-24.

142. Lack of regulatory enforcement prompted the Celler Committee to report that "[f]or a period of almost 45 years, lethargy and indifference have characterized [the Commission's] attitude, laxity and inefficiency its procedures, and frustration and ineffectiveness its administration of the regulatory features of the shipping acts." H.R. REP. No. 1419, 87th Cong., 2d Sess. 359-60 (1962). See also JoINT Economic Comm., Discriminatory Ocean Freight Rates and the Balance of Payments, S. REP. No. 1, 89th Cong., 1st Sess. 3-6, 21-34 (1965).

143. Reorganization Plan No. 7 of 1961, $\S 101-305,75$ Stat. 840.

144. "NAUK" refers to the North Atlantic/United Kingdom Conference, which was involved in the investigation.

145. Investigation of Ocean Rate Structures in the Trade between the United States North Atlantic Ports and Ports in the United Kingdom and Eire, 12 F.M.C. 34, 34 (1968).

146. Gordon, Shipping Regulation and the Federal Maritime Commission, $37 \mathrm{U}$. CHI. L. Rev. 90, 148-51 (1969); May, The Status of Federal Maritime Commission Shipping Regulation under Principles of International Law, 54 GEO. L.J. 794, 804-06 (1966). Under section 21 of the Shipping Act, the Federal Maritime Commission may require the filing of any document "appertaining to the busimess of such carrier ..." 46 U.S.C. $\$ 820$ (1964). 
lateral attempt at regulation as a violation of their territorial jurisdiction. ${ }^{147}$ Rather than force compliance and risk damage to relations with its principle trading partners, the United States settled for a compromise worked out under the auspices of the Organization for Economic Cooperation and Development (OECD). The United States agreed to refram fron the enforcement of those orders still outstanding in order to obtam part of the necessary information through diplomatic channels. ${ }^{148}$

The results of the investigation that followed this controversy illustrate the ineffectiveness of direct rate regulation under the Shipping Act. The examiner appointed by the Commission ruled early in the proceedings that the entire conference tariff-consisting of over 1,500 individual rates and several hundred classifications-nust be scrutinized, thus delaying the proceedings for many months of investigation and testimony. ${ }^{149}$ Two and one-half years after the original order of investigation, ${ }^{150}$ the Commission rendered its final decision, disapproving only seven of the rates considered. ${ }^{151}$ The Commission ordered the filing of lower rates on these seven items along with justifications for them based on cost, value of service, or other transport conditions. ${ }^{152}$ Subsequently, lower rates on these items were filed and accepted by the Commission, although no attempt was made by the conference to justify the new rates, nor by the Commission to evaluate them as reasonable under the criteria of section $18(\mathrm{~b})(5) .{ }^{153}$

This example of delay and ineffectiveness is not unique. Given the Commission's regulatory framework, rigorous evaluation of rates is virtually impossible. By allowing discriminatory value-of-service pricing ${ }^{154}$ the Commission permits one class of commodities, highly-valued goods, to subsidize the movement of other, cheaper commodities. Thus, "cross subsidization" occurs throughout the conference tariff, and makes the evaluation of a reasonable rate level on a single commodity impossible. Only by judging the conference tariff as a whole under a fair-rate-

147. From 1962 to 1966 , a total of 24 formal diplomatic protests were received, representing 72 governments, condemning the FMC orders. May, supra note 146, at 808. In addition, the British Parliament enacted a law making it illegal to comply with orders such as these. Shipping Contracts and Commercial Documents Act 1964, c.87, \& 2 .

148. Agreed Minute Provides for Exchange of Shipping Information, 52 DEP'T State BulL. 188 (1965).

149. Gordon, supra note 146 , at 153.

150. 30 Fed. Reg. 15600 (1965).

151. 12 F.M.C. at $63-67$.

152. Id.

153. Gordon, Shipping Regulation and the Federal Maritime Commission, 37 U. CHI. L. REv. 256, 282-93 (1970).

154. See note 28 supra and accompanying text. 
of-return-on-capital method is reasonable evaluation possible. ${ }^{165} \mathrm{Un}$ fortunately, the Commission is unable to use this method of rate evaluation in foreign commerce ${ }^{156}$ since, as the NAUK Investigation shows, it lacks the ability to obtain complete cost and imvestment information necessary for the fair-rate-of-return method without damaging foreign relations.

The Commission's lack of effectiveness is also attributable to its overseeing the activities of more than 100 different conferences, each utilizing tariffs comprising thousands of different rates and classifications. Thus, the prolonged investigations required in each individual rate case ${ }^{157}$ preclude consideration of a meaningful portion of all conference rates and shippers' coinplaints. ${ }^{168}$

Soine observers argue that the Commission's ineffectiveness in direct rate regulation is due to bureaucratic weaknesses, rather than any inherent defects in direct rate regulation under the Shipping Act. ${ }^{160}$ However, it is doubtful that meaningful direct rate regulation can occur without utilizing a fair-rate-of-return-on-capital test that measures the rate level of the conference tariff as a whole. ${ }^{100}$ Such a test requires ready access to coinplete and reliable statistics regarding the value of capital

155. Gordon, supra note 153 , at 267 . See generally LockLIN, supra note 20 , at $352-87$.

156. See Gordon, supra note 153 , at 267. The Interstate Commerce Commission does employ the "fair rate of return" method; the Federal Maritime Commission has made only limited use of it in purely domestic trade. LockLIN 336, 760.

157. Besides the NAUK Investigation, there have only been four other direct rate regulation cases of any significance under seetion 18(b)(5) of the Shipping Act of 1916, 46 U.S.C. $\$ 817$ (b)(5) (1964). The shortest proceeding appears to have taken two years for the Commission to decide, and in none of the cases was any rate declared unreasonable. Iron and Steel Rates, Export-Import, 9 F.M.C. 180 (1965) (investigation begun in 1963); Outbound Rates Affecting the Exportation of HighPressure Boilers (Utility Type), Parts, and Related Structural Components, 9 F.M.C. 441 (1966); Calcutta, East Coast of India and East Pakistan/U.S.A. Conference, 11 F.M.C. 43 (1967) (investigation begun in 1965, but never proceeding to a consideration of section $18(\mathrm{~b})(5)$ issues due to lengthy litigation over the Commission's authority to issue subpoenas to the conferences requiring production of documents); Investigation of Rates in the Hong Kong-United States Atlantic and Gulf Trade, 11 F.M.C. 168 (1967) (investigation begun in 1962). In the last case, the Commission avoided the whole reasonable-rate issue by holding that the case had been mooted by the fiveyear delay, due to outdated economic evidence and the fact that the competing line that had requested the investigation had been forced out of the trade, thus renewing rate stability. 11 F.M.C. at 173. See generally Gordon, supra note 146, at 130-58; Gordon, supra note 153 , at 60 .

158. Only isolated rate cases have been considered by the Commission acting on complaints of discrimination filed by shippers under sections 16 and 17 of the Act [46 U.S.C. $\$ \S 815-16$ (1964)]. See text accompanying note 136 supra. In such cases the cost of lengthy litigation prevents many individual shippers from taking advantage of these sections. See Gordon, supra note 146, at 130; BeVier, supra note 23, at 87 .

159. See, e.g., Lowenfeld, supra note 129, at 66-68.

160. See note 155 supra and accompanying text. 
investment, costs, total revenue, and other data, something strongly resisted by the conferences and the maritime powers.

Thus, as Professor Gordon argues, ${ }^{161}$ it may be better to concentrate on "indirect rate regulation," that is, a method of controlling the level of freight rates by circumscribing the conferences' practices and monopoly powers. For example, the requirement that no deferred rebates may be used in United States trade, ${ }^{162}$ or that dual rate contracts not provide a contract rate lower than 85 percent of the ordinary rate, ${ }^{103}$ may do more to keep rate levels down, by enhancing the possibility of competition, than sporadically successful direct rate regulation.

\section{Direct Rate Regulation and the Developing Countries}

For at least three separate reasons most developing countries have not been tempted to follow the United States example of unilateral direct rate regulation. ${ }^{104}$ First, they realize that if the world's most powerful nation, economically and politically, has not been successful in attempting to regulate conference rates, their chances, acting unilaterally and with much less influence, are virtually nonexistent. Second, most developing countries are more dependent on foreign trade than the United States and thus even more wary of foreign-relations repercussions from attempts at unilateral regulation. ${ }^{165}$ Third, direct rate regulation is too costly. To be carried out effectively, it requires a large and highly skilled bureaucracy to constantly scrutinize thousands of conference rates, and with such poor chances of success, the developing countries have not been eager to allocate their resources to it. ${ }^{166}$

There is an additional reason why unilateral direct rate regulation is not a viable policy for the developing countries as a group and should not be stressed within UNCTAD. Even conceding the validity of such

161. Gordon, supra note 153, at 294.

162. 46 U.S.C. $\$ 812$ (1964).

163. 46 U.S.C. $\$ 813 a(1964)$.

164. See, e.g., UNITED Nations ECONOMIC COMMISSION FOR ASIA AND tHe FAR EAST, Review of Legislative and Other Experience Relating to Ocean Shipping and Freight Rates, in REPORT OF THE ECAFE WOREING PARTY ON SHIPPING AND OCEAN Freight Rates and Related Papers 41-43 (1968). One exception is Brazil, which in 1937 passed a law to regulate conference rates and practices. Because of the same difficulties encountered by the United States in asserting its jurisdiction in foreign commerce, the rate-regulation aspects of the law lave yet to be applied. MARX, supra note 4 , at $98-99$.

165. See note 147 supra and accompanying text.

166. A survey done by the Secretariat of UNCTAD reveals that, while some govcrnments do negotiate over rates with conferences on an ad hoc basis, most lack a system of legislation or a specialized agency to do so. Consultation in Shipping, supra note 92 , at $135-247$. 
regulation under modern principles of territorial jurisdiction, ${ }^{107}$ it is obvious that a proliferation of "Federal Maritime Commissions" would create interminable problems of conflicting regulations between states fixing different rates in the same trade. ${ }^{108}$ While an international regulatory agency would solve the problem of conflict between states, this is only a remote possibility; there is no such international agency in any sphere of commercial activity. ${ }^{109}$ Instead, the answer to developingcountry problems lies beyond unilateral direct rate regulation.

\section{B. Development of Merchant Marines}

Developing-country attempts to increase their merchant shipping fleets represent a principal method of attaining added influence in conference ratemaking, either by providing competition froin without the conference or through representation within it. ${ }^{170}$ Most governments give substantial assistance to their privately owned merchant fleets through direct subsidies or cargo reservation schenes. ${ }^{171}$ Subsidies are especially important to developing countries, where the high capital costs involved in building merchant fleets are aggravated by the lack of private capital available for investunent. ${ }^{172}$ In some cases, several developing countries within the same region have pooled their merchant fleets, thus benefiting from economies of scale and increased markets for their shipping services. This practice, if continued, could challenge the traditional supremacy of the maritime nations. ${ }^{173}$

The other basic form of governmental assistance available to merchant marines is cargo reservation. Here, legislation requires that a specified amount of import or export cargo be reserved for shipping on nationally owned vessels. ${ }^{174}$ An increasing number of developing

167. For an analysis supporting the legality of FMC regulations under international law, see May, supra note 146 , at 818-46.

168. Id. at 846,850 .

169. Lowenfeld, supra note 129 , at $69-70$.

170. Maritime Freight Rates in the Foreign Trade of Latin America, supra note 8 , at 4.

171. Establishment or Expansion of Merchant Marines in Developing Countries 47, U.N. Doc. TD/26/Rev. 1 (1968); The Nature and Extent of Cargo Reservation 6-7, U.N. Doc. TD/B/C. 4/63 \& TD/B/C. 4/63/Add. 1 (1970).

172. Establishment or Expansion of Merchant Marines in Developing Countries, supra note 171, at 47 . International organizations, such as the World Bank and the Inter-American Development Bank, have been virtually inactive in securing loans for the expansion of developing countries' merchant marines. Id. at 45.

173. For example, the Gran Colounbia Line was formed by the governments of Colombia, Venezuela and Ecuador to combat what they believed to be unreasonably high conference rates. MARX, supra note 4, at 254. Shipping pools have also been established among Asian countries. See United Nations Economic Commission for ASIA AND THE FAR EAST, Scope for Regional Co-operation in the field of Shipping and Ocean Freight Rates, in OCEAN Freight Rates aNd Related PaPERS 90 (1968).

174. For a discussion of cargo reservation schemes and their application sec The Nature and Extent of Cargo Reservation, supra note 171, at 6-18. 
countries have turned to such legislation both as a means of ensuring the survival of their infant merchant fleets against established developedcountry lines ${ }^{175}$ and as a method of retaliating against allegedly injurious conference practices. ${ }^{176}$ Bilateral cargo reservation schemes are not uncommon, ${ }^{177}$ and the contracting parties of the Latin American Free Trade Association (LAFTA) have recently signed a Convention on Waterborne Transportation that will reserve the bulk of their trade to the fleets of the contracting party states. ${ }^{178}$ These agreements are vigorously opposed by the traditional maritime powers that export shipping services, ${ }^{179}$ and the countries that employ them face retaliation against their exports

175. See the replies of governments to a survey carried out by UNCTAD, id. at 29-163, Add. 1.

176. For example, Brazil has passed a law requiring that 70 percent of all imports must travel in Brazilian bottoms, in retaliation against the reestablishment of deferred rebates used by the Europe-Brazil conference to exclude the competition of Brazil's own Lloyd Brasileiro Liue. S. StuRMeY, BRITISH SHIPPING aNd World COMPETTIION 198 (1962).

177. For example, two recent agreements between United States and Brazilian shipping lines provide for equal sharing of all United States-to-Brazil cargoes that are financed in whole or in part by either government. The Federal Maritime Commission has approved the agreements. Wall St. J., Oct. 27, 1970, at 12, col. 2.

178. For a copy of the Convention, see Convenio de Transporte por Agua, 2 ALALC [Asociación Latino-Americana de Libre Comercio]-SínTesis Mensual, Aug. 1966, at 14. To date, only three of the five ratifications needed have been obtained. Tratados, Protocolos y Convenios Suscritos en el Marco Jurídico de la Asociación, 6 ALALC-SínTESIS MENSUAL 8, 13 (1970).

A result of pressure from the active Latin American Shipowners' Association (ALAMAR), the Convention was signed in May 1966 by representatives of the contracting parties sitting as the Council on Transport and communications. Informe Final de la Primera Reunión del Consejo de Transporte y Comunicaciones de la Asociación Latino-Americana de Libre Comercio, LAFTA doc. ALALC/CC/I/Informe (1966); Antecedentes y Espiritu del Convenio Acuático de la ALALC, ALALCSínTESIS Mensual, June 1966, at 21-22. It provides for the reservation of nontanker trade between the contracting parties to the merchant shipping fleets of each of them. The Convention does not explicitly describe how this multilateral cargo reservation scheme will work, but provides for the establishment of a Commission to draft a set of regulations that will implement the basic idea. A draft set of rules adopted by the Commission in 1967 has not been approved by the necessary majority of states. Convenio de Transporte por Agua: Su Reglamentación, 4 ALALC_SíNTEsIs MENSUAL 259 (1968).

The Convention also authorizes the eventual establishment of shipping conferences "or similar organs" consisting of all Latin American shipowners, with the power to set rates which will apply only if the "competent authorities" of each contracting party do not object within a period of 30 days. Article 4 provides that non-LAFTA shipowners can participate in intrazonal transport, subject to the same rules as LAFTA shipowners, when this does not inferfere with the expansion of the merchant marmes of the contracting parties. Thus, the conventiou also attempts to subject foreign shipowners to its rate regulations.

Understandably, foreign shipowners have objected to this plan; even the United States Federal Maritime Commission and the Department of State have registered disapproval. E.B. HaAs \& P.C. Schmitter, The Politics of Economics in Latin American Regronalism 14 (3U. Denver Monograph Series in World Affairs 1965-66).

179. For opposition to the Brazil-United States shipowners agreement to divide 
and shipping lines. The developing countries, however, citing their lack of merchant fleets, are now lobbying within UNCTAD for developedcountry recognition of their right to special assistance in shipping. ${ }^{180}$

Governmental assistance to shipping also has important economic repercussions. Both subsidies and cargo reservation are likely to cause diseconomies, especially inefficiency of operation and overcapacity of shipping space. ${ }^{181}$ This leads some economists to argue that ocean shipping should only be carried on by countries that have a comparative advantage, rather than allowing the developing countries to waste their revenues by investing in an inefficient operation. ${ }^{182}$ However, comparative advantage is a limited and static theory which says that a country should trade only those commodities which it can produce more efficiently relative to other countries at a given point in time. It does not indicate when long-range investunents should be made to develop efficiency in particular industries. Indeed, the enlarged merchant fleet's favorable effect on a country's deteriorating balance of payments, or the increased bargaining power that it creates vis-á-vis the conferences may well compensate for short-term operating losses. ${ }^{183}$

Given the developing countries' mistrust of the conference system and their degree of dependence on foreign shipping services, ${ }^{184}$ their desire for development of their own merchant fleets is understandable. Within UNCTAD, this development has been stressed by representatives of the developing states and by the Secretariat. ${ }^{185}$ However, it is inportant not to assume that the growth of developing-country merchant marines is the whole solution to the problem of ratemaking in the liner conferences. While a large national merchant marine may help to control general rate levels, by increasing the country's bargaining power within the conference structure, or by providing competition from without, its existence cannot solve imdividual shipper-shipowner rate problems that arise, for example, when an Argentine importer disputes the freight rate charged by a Brazilian liner on power tools manufactured in the United States. In addition, the development of a merchant fleet is a long-

thier countries' trade [see note 177 supra], see Wall St. J., Oct. 27, 1970, at 12 , col. 2.

54.

180. See Recommendation A.IV.22, Final Act, in 1 ProceEdings, supra note 2, at

181. The Nature and Extent of Cargo Reservation, supra note 171, at 11.

182. S. EnKe \& V. SAlerA, INTERnational Economics, 328-29 (2d ed. 1951).

183. The Nature and Extent of Cargo Reservation, supra note 171, at 2-3. For a similar justification of the development of a strong United States merchant fleet despite a comparative disadvantage in this industry, see McGee, supra note 21, at 307-14.

184. See notes 8, 9 supra and accompanying text.

185. See Resolution 9(IV) of the Committee on Shipping, requesting financial assistance for the acquisition of ships by developing countries, in Report of the Committee on Shipping on its Fourth Session 21, U.N. Doc. TD/B/301 (1970). 
range policy; its indirect effects on the level of freight rates and the practices of liner conferences result in substantial changes only after many years. Tlius it does not preclude the establishment of other policies to affect conference ratemaking practices at the present time, before the effects of an enlarged shipping fleet can be felt.

Cargo reservation scheines, although they have been studied, ${ }^{186}$ have not been strongly einphasized in UNCTAD resolutions as a general policy to be followed by developing countries. Such schemes liave inerit only as a method of protecting an infant shipping industry until it is able to operate efficiently. As a long-range policy, cargo reservation schemes are antithetical to the present trend toward free trade, exemplified by the GATT atteinpts to decrease tariffs on imports among its contracting parties. $^{187}$ In conclusion, investinent by developing countries in their merchant shipping fleets, and cargo reservation schemes for their imtial protection, while desirable as means of correcting the present imbalance in the transport system, ${ }^{188}$ do not by themselves provide a rational scheme of ratemaking in ocean transport services.

\section{Establishment of Negotiation Procedures}

Instead of employing a system of direct rate regulation, as the United States has done, most developing countries that have attempted to deal with the conferences have followed the example set by Western Europe $^{180}$ and established additional anticoinpetitive groups-shippers' councils-to counterbalance the rateinaking power of the conferences through direct private negotiation. This negotiation procedure is termed consultation.

Although few shippers' councils exist outside of Western Europe, ${ }^{190}$ the efforts of UNCTAD and other international economic organizations ${ }^{101}$ have focused attention on their importance. In several develop-

186. See The Nature and Extent of Cargo Reservation, supra note 171.

187. See generally K.W. DAM, supra note 73.

188. See notes 8,9 supra and accompanying text.

189. Twelve national shippers' councils exist in Western Europe, each composed of representatives of all the countries' shippers and recognized by the shipowners as legitimate partners for negotiation. The system grew out of a general feeling that many conference practices not discussed on an individual shipper-shipowner level, such as publication of tariffs and notification of rate increases, should be the subject of negotiation and discussion. By the terms of a Note of Understanding signed in 1964 by the Western European shippers' associations and the conference lines, shippers and shipowners now meet and consult nationally as well as regionally. There are two important characteristics of these meetings: First, governments do not take part in them; and second, only matters of general principle and broad areas of mutual interest, not the level or structure of freight rates, are subjects for discussion. Consultation in Shipping, supra note 92, at 29-50.

190. Id. at $14,135$.

191. See text accompanymg notes $91-93,111$ supra. 
ing countries, the national government has also taken an active role in the establishunent of shippers' councils and consultation machinery.

\section{The Indian Example}

The leader in this area has been the Government of India, which in 1956 launched a drive to expand and diversify her export trade. ${ }^{102}$ Recognizing the importance of ocean transport to this plan, the Government, in 1959, established the Freight Investigation Bureau (FIB) under the Ministry of Transport. ${ }^{103}$ The FIB's functions included the investigation of shippers' complaints of high or discriminatory freight rates and the duty to secure "necessary adjustments."104 Through the agency's guidance, a "discussion formula" was agreed on between the three major Indian shippers' associations and the conferences. The country's principal conference, the India-UK/Continent Conference, subscribed to the formula through an intraconference agreement between the Indian and foreign lines. The formula provides for a period of consultations with the shippers' associations six months before any overall rate increase. If no agreement on the amount of, or need for, the increase is reached within three months of the time in which the new rate is to take effect, the matter is referred to the Indian Government for consultation with the conference. Similar procedures, with shight differences in the time periods, apply to rate increases on individual commodities. Overall mcreases within less than two years of each other are prohibited. ${ }^{105}$ In recent years, this process has resulted in over 450 individual rate reductions. ${ }^{106}$

Two principal features of the Indian consultation procedure ac-

192. Sarangan, Liner Shipping in India's Overseas Trade 103, U.N. Doc. TD/B/C. 4/31 (1967).

193. Id.

194. Id. In practice, the agency has acted as an information service for shippers by collecting freight tariffs and analyzing their effects on Indian trade, in some cases lending factual support to shippers' complaints. Thus, while not directly attempting to fix or disapprove rates, the FIB has succeeded in making the conferences less secretive and inore receptive to the interests of Indian shippers. Id. at 104.

Closer to direct rate regulation is the procedure used by the Maritine Freight Counmission, established soon after the FIB to advise the government when requested on matters relating to maritime freight rates. The first such request was made in 1963, when a 15 percent general rate increase in the India-UK/Continent Conference failed to secure the agreement of shippers in accordance with the discussion formula [see text accompanying note 195 infra]. The Commission ruled that, on the basis of data presented to it, a rate increase of no more than 7.5 percent was in order. The Government accepted the ruling, and forwarded it to the conference, which rejected it, offerimg instead an increase of 12.5 percent. Upon the objections of the Indian Government, the general rate increase was finally lowered to 10 percent. Id. at 109-06.

195. Consultation in Shipping, supra note 92, at 97-112.

196. N. Singh, supra note 53, at 110. For an example, see note 194 supra. 
count for its success. First, it is the only procedure of its kind in which particular freight rates are a topic of negotiation. ${ }^{197}$ Since freight rates are the subjects most frequently disputed, shippers who individually lack the bargaining power and resources to carry on rate investigations have much to gain by association into shippers' councils. Second, the Indian consultation formula alone mcludes active government participation. ${ }^{108}$ This participation is important both in directing the establishment of a well-organized shippers' council and in providing the added pohtical influence necessary when dealing with international concerns such as liner conferences.

\section{The Establishment of Consultation Machinery as a General Policy for the Developing Countries}

Resolutions passed at the UNCTAD Conferences of $1964^{198}$ and $1968^{200}$ reflect moreased developing-country desire for governmental involvement in the establishment of consultation procedures that include negotiation of imdividual rate disputes. This is essentially the same formula as that used by the Indian Government, whose regulations may serve as a model for other developing countries.

Consultation along the lines of the Indian model has several advantages over unilateral direct rate regulation, on the one hand, and a laissez faire policy on the other. Consultation does not involve the saine danger of international conflict that has frustrated past attempts at unilateral direct rate regulation, ${ }^{201}$ since there is no national agency which fixes a binding rate on foreign commerce. Such a system already exists in Western Europe; ${ }^{202}$ and although rate matters are not yet recognized topics of discussion in the European consultation procedure, these countries, including important maritime nations, seem more open to this method of ratemaking procedure than direct regulation. ${ }^{203}$

197. Consultation in Shipping, supra note 92, at 20. In other countries with consultation machinery, rate controversies are left up to individual shippers. See note 189 supro.

198. Id. at 24. See note 194 supra and accompanying text. The British Royal Commission on Shipping Rings in 1909 recommended the participation of the government in shipper-shipowner consultations, since shippers' councils, representing only exporters and importers, do not reflect the interests of producers, consumers, and the econoiny as a whole. RePort of the ROYAL COMMISSION ON SHIPPING RINGS, supra note 17 , at $85-90$.

199. See text accompanying notes 91-93 supra.

200. See text accompanying notes 110-12 supra.

201. See text accompanying notes 141-48 supra.

202. See note 189 supra.

203. Thus, the developed countries, including the maritime powers, agreed, in the Common Measure of Understanding adopted at the first UNCTAD Conference, on the necessity for consultation procedures and, at UNCTAD-II, on the need for government involvement in this area. See notes 92,110 supra. 
In addition, by allowing the private parties involved to settle most disputes, consultation obviates the consideration of thousands of individual freight rates by a single bureaucratic agency that must attempt to disapprove the "unreasonable" ones. ${ }^{204}$ Instead, the governmental agency that administers the consultation machinery need only intervene after negotiations have failed; then it independently determines an acceptable rate. ${ }^{205}$ An even better solution would substitute an international arbitration authority to consider disputes not resolved at the lower levels, ${ }^{206}$ since this would neutralize any conference allegations as to the partiality of a purely national agency.

Finally, instead of the present laissez faire policies, which give the conference an unfair bargaining advantage over individual shippers, consultation provides more balance in shipper-shipowner rate negotiations, just as a labor union enhances the bargaining position of workers. ${ }^{207}$

The principal obstacle to the establishment of consultation machinery is the conferences' failure to recognize shippers' councils as partners in meaningful rate negotiations. This recognition will only come as a result of increased pressure on the shipowners from governments, especially those of the maritime powers that now control shipping supply. Thus, political pressure will continue within UNCTAD for the adoption of a world-wide system of consultation.

There is an additional need for governmental intervention that has not yet been stated. Meaningful consultation is hampered when the monopoly power of an individual conference is great. For this reason, private negotiation should be coupled with legislation that mitigates the anticompetitive power of the conferences operating in a given country's trade. The following requirements-many of them to be found in the United States Shipping Act of $1916^{208}$-are examples of such legislation:

204. This is especially important for developing countries which lack the resources to maintain a Federal Maritime Commission-type regulatory agency. See note 166 supra and accompanying text.

205. Such is the government's role under the Indian procedures. See note 194 supra.

206. This type of plan was envisaged by the group of experts who reported to the first UNCTAD Conference on economic effects of the liner conference system. 1 Proceedngs, Annex G, at 230, 285.

207. There is an important difference between negotiation over labor contracts and consultation in shipping. In consultation, under present rate structures, the freight rate on a commodity is unrelated to the actual cost of service for that commodity. See notes 26-28 supra and accompanying text. Under these circumstances, a decrease in one rate may mean that another rate in a different class must carry more of the total cost, thus raising disputes between shippers as to which rates should be lower. But, at least in terms of bargaiming for general rate deereases, or against general rate increases, there should be no problem of securing shipper unanimity.

208. 46 U.S.C. $\$ \S 801-42$ (1964), as amended, 46 U.S.C. $\$ \$ 801-42$ (Supp. V, 1970). 
[1] conference membership should be open to any shipping line that wishes to join; ${ }^{200}$

[2] the full texts of all conference agreements should be published and subject to approval; $; 210$

[3] the conference should publish and make available to shippers a complete copy of its current tariff; 211

[4] the use of deferred rebates should be prohibited;212

[5] dual rate contracts should be allowed only when the ordinary rate does not exceed the contract rate by more than a certain percentage, and when other guidelines set by the government are coinplied with; ${ }^{213}$

[6] the shipping lines should periodically supply the government with reliable figures concerning their total revenue, costs, profits, and other information useful in evaluating the need for rate increases. $^{214}$

None of these regulations threatens the ratemaking powers of conferences as much as direct rate regulation. However, taken together and coupled with consultation procedures, they represent a potential threat of considerable magnitude to the conferences' monopoly power. Moreover, since they are in a form that is more acceptable to most governments than direct rate regulation, they represent a more promising general policy that is geared to the needs of developing nations.

\section{CONCLUSION}

The conference system remains a 19 th-century institution at a time when other areas of international trade-for example, tariff and nontariff barriers on imports-are being liberalized and rationalized by international agreement. ${ }^{215}$ Unilateral rate regulation hardly seems an international solution in furtherance of free trade and must be rejected as a general policy to be followed by the developing nations.

As an immediate means of dealing with the conferences, a generalized system of shipper-shipowner consultation in each country provides a beneficial alternative to the present laissez faire system. This alternative both enhances the bargaining power of shippers and avoids the dangers of international conflict inherent in unilateral rate regulation. Consultation machinery also offers the opportunity to establish an international arbitration authority, once the system becomes generalized.

209. 46 U.S.C. $\$ 813$ (1964).

210. 46 U.S.C. $\$ 814$ (1964).

211. 46 U.S.C. $\$ 817$ (b)(1) (Supp. V, 1970).

212. 46 U.S.C. $\$ 812$ (1964).

213. 46 U.S.C. $\$ 813 \mathrm{a}$ (1964).

214. 46 U.S.C. $\S 820$ (1964).

215. See generally K.W. DAM, supra note 73. 
The establishment of such an authority creates the possibility of an international solution to the most international of industries, either through international regulation of conference rates or by the deinolition of the conference system in favor of internationally controlled competition in liner services.

The role of developing-country governments in the establishment and maintenance of consultation machinery is crucial. Successful rate negotiations between shippers' councils and the conferences depend upon government willingness to exert influence when the parties cannot agree. In addition, by regulating conference practices that are indirectly related to ratemaking, ${ }^{216}$ governments can lessen the conferences' anticompetitive power, which threatens successful shipper-shipowner negotiations.

The program just described would be most successfully implemented as a general developing-country policy through the efforts of an international organization such as UNCTAD. Consultation procedures can be complex, and expert advice supplied through the UNCTAD Secretariat would be useful in assuring workable procedures as well as uniformity in national legislation, which would help minimize conflict between nations. By promoting complementary national policies, UNCTAD could achieve a more rational ratemaking systein in the liner industry even though opposition to international regulation renders a multilateral convention impossible at the present time.

Stephen Zamora

216. See text accompanying notes 209-14 supra. 